\title{
Article \\ Coronavirus-Driven Digitalization of In-Person Communities. Analysis of the Catholic Church Online Response in Spain during the Pandemic
}

\author{
Alba Sabaté Gauxachs ${ }^{1, * \mathbb{D}}$, José María Albalad Aiguabella ${ }^{2}$ and Miriam Diez Bosch ${ }^{1}$ (D) \\ 1 Blanquerna Observatory on Media, Religion and Culture, Ramon Llull University, 08001 Barcelona, Spain; \\ miriamdb@blanquerna.url.edu \\ 2 Facultad de Comunicación, Universidad San Jorge, 50830 Zaragoza, Spain; jmalbalad@usj.es \\ * Correspondence: albasg@blanquerna.url.edu; Tel.: +34-932-533-108
}

check for

updates

Citation: Sabaté Gauxachs, Alba, José María Albalad Aiguabella, and Miriam Diez Bosch. 2021.

Coronavirus-Driven Digitalization of In-Person Communities. Analysis of the Catholic Church Online Response in Spain during the Pandemic. Religions 12: 311. https:// doi.org/10.3390/rel12050311

Academic Editor: Enzo Pace

Received: 31 March 2021

Accepted: 21 April 2021

Published: 28 April 2021

Publisher's Note: MDPI stays neutral with regard to jurisdictional claims in published maps and institutional affiliations.

Copyright: (c) 2021 by the authors. Licensee MDPI, Basel, Switzerland. This article is an open access article distributed under the terms and conditions of the Creative Commons Attribution (CC BY) license (https:// creativecommons.org/licenses/by/ $4.0 /)$.

\begin{abstract}
COVID-19 has driven several global offline communities to go online. Restrictions to the free movement of people in response to the coronavirus pandemic triggered a profound rethinking of jobs, products and services, and among them, the activities of religious communities, which are well consolidated in the offline sphere. In Spain, since the lockdown established by the government in March 2020, the Catholic Church has reinvented its activity, as all the churches and other places of worship have been closed. This constituted a considerable challenge, considering the history and dynamics of the institution. This paper aims to analyze how Catholicism, as one of the most consolidated offline communities, reworked its communication, going online in a matter of days. With this objective, researchers surveyed each and every one of the 70 Spanish dioceses, taking them as representatives of the global Catholic community in the country. Their responses are complemented with an in-depth interview with the Director of Communications at the Spanish Conference of Bishops. The results highlight the huge and unprecedented step towards the digitalization of the community through consistent, creative and efficient action. New methods, platforms and languages have been implemented, even broadening community membership. Despite an offline essence that is still detected in some decisions, this pandemic has brought a new communicative paradigm to the Spanish Catholic community. Digitalization has been consolidated whilst preserving the best aspects of direct contact and action.
\end{abstract}

Keywords: coronavirus; COVID-19; church; Catholicism; Spain; online religion; digital religion; pandemic

\section{Introduction}

The coronavirus crisis has forced individuals, communities and organizations to increase and accelerate their digital activity (Campbell 2020; Koeze and Popper 2020; Lowenthal et al. 2020; Pew Research 2020; Statista 2020a, 2020b). Digital media and social networks have, therefore, played a prominent role (Binder 2020; Casero-Ripollés 2020; Fischer 2020; Igartua et al. 2020) during the pandemic.

Restrictions on the free movement of people triggered a profound reinvention of sectors, products and services, among which is religious attendance (Barber 2020; SánchezCamacho 2020). In this context, as revealed by Google Trends, the digital search for religious services and spiritual issues has multiplied in Spain (González 2020). On a scale of zero to one hundred, the term Live Mass increased 97 points between March 1 and April 11 2020 - a growing trend, according to Google data, which, in that same time span, led to peak popularity of searches such as heaven, blessing, God, Pope Francis and prayer.

On one hand, given the suppression of public worship in most churches, believers turned to the internet to continue practicing during the toughest weeks of the pandemic (Campbell 2020; MacDonald et al. 2020), following the recommendations of health care 
institutions and also those of religious ones, such as the Holy See, the Spanish Episcopal Conference and the Anglican Church in the United Kingdom (Aguirregomezcorta 2020; Parish 2020). In the cases of Christianity, Islam, Judaism and Sikhism, the pandemic coincided with some of the most emblematic dates in the liturgical calendar. On the other hand, there were those who returned to their beliefs, pored over existential questions or discovered a transcendent vision of life, given that "in situations where dissatisfaction, disorientation and feelings of vulnerability prevail, religion is enhanced, turning to the meta-social as hope, help and response to the unknown" (Celia Perera and Cruz 2009; Volf 2015).

Since the state of alarm was declared (Government of Spain 2020, of March 14th 2020), the Catholic Church, like other religious institutions, has been forced to find new ways to provide human and spiritual accompaniment. Apart from the user profile, which could be the specific subject of further investigation, the objective of this work is to analyze the communicative response that the Catholic community has had in Spain, represented by the 70 dioceses of the country. It is about describing how they dealt with restrictions, what services they provided, and on which platforms. Finally, we want to know which results their initiatives had, and in what way this faith community, well consolidated at the face-to-face level, transferred its action to the online world.

Díez-Bosch, Micó-Sanz and Sabaté-Gauxachs already highlighted in 2018 that Catholics had discovered digital possibilities and did not hesitate to get the most out of them; but what role does the digital space play in Spanish dioceses' communication (BaraybarFernández et al. 2020)? Is the provision adapted to this growing demand, aligned with the new media ecosystem (Celli 2013)? Has confinement triggered the necessary adaptation (Campbell 2020)?

When investigating the services provided by the dioceses' communication departments (media delegations, in ecclesial slang), the article reflects that the coronavirus crisis has constituted an unprecedented test bed in a global community like the Catholic Church-a millenary institution in which, bowed under the weight of its own history, experimentation and changes are not as agile as in new organizations (Pou-Amérigo 2008; Díez-Bosch 2015). The restrictions derived from the pandemic, as stated in this article, have accelerated a digitalization that, although initiated in the last decade, had encountered a certain reluctance (Soberón 2015).

\section{The State of the Art}

The construction of online communities has attracted a significant amount of the academic research on digital communication in the last two decades (Campbell 2021; Hoover 2016). Digital communities are defined as collectives based on a virtual space and that revolve around some specific motivation or aspect of common interest-something which acts as a link between their members (Caldwell and Bugby 2018; Gupta and Kim 2004; Castells 2001; Kim 2000; Preece 2000; Graham 1999; Rheingold 1993). For Eilers (1994), the very concept of communication means having something in common. Unlike in-person, face-to-face communities, online communities can have a wider space and time range and follow an asynchronous rhythm of interaction, as well as accurately and traceably record all the activity that takes place there (Díez-Bosch et al. 2018; Campbell 2005).

They have been considered inauthentic spaces or not places at all (Holtzman 1994; Augé 1994). Their attributes mean that they have been constantly compared with the face-to-face space (Campbell and Garner 2016). In fact, for authors like Lajoie (1996), Helland (2005), and Campbell (2012), digital communities are an extension of physical communities, although without replacing them. According to Turkle (1995), individuals look to virtual communities for a genuine experience, underlining that the internet connects people with people, and not with screens (Wellman et al. 1996). Campbell and Garner (2016) and Hoover (2016) point out that these new spaces empower practices and behaviors that force us to rethink the dynamics of face-to-face communities. 
Digital communities are also a place where religions can carry out their activities (Piff and Warburg 2005). Within the field of study and conceptualization of this digitalization, Campbell $(2005,2021)$ considers that the internet is not simply an information repository but rather a social space in which "networked" religion can function. Indeed, the study of the generation of religious digital communities (Hoover and Kaneva 2009) occupies an essential part of the existing literature under the umbrella of the discipline known as mediatization of religion (Hjarvard 2011). Reising (2006) affirms that digital religious communities, rather than promoting themselves, should work on the engagement of their members in the virtual space.

Hoover and Kaneva (2009) emphasize that the internet can be a challenge for many digital religious communities in terms of identity, authority and engagement, as it turns into an immense marketplace where all manner of discourses can be found. Lövheim (2004) highlights that the online space empowers users to investigate and access knowledge before making decisions regarding their religious identity. Beyond this, for the author, this identity is not constructed ex nihilo, but rather is the result of social, relational and media interactions. Furthermore, the online space can reinforce religious identity and beliefs in the same way that the offline space does, or conversely, it can generate doubts about them (Kołodziejska 2020; Abdel-Fadil 2017). For Evolvi (2017), "the Internet differs somewhat from other media in its ability to provide a space for more nuanced identity negotiations and discourse formations". Hoover (2006) highlights the legitimizing power of communication platforms.

The internet is, thus, a space in which believers can freely interact on their own beliefs outside of the dynamics and conditions of offline communities; in a way, this might seem individualized, fragmented and to break the institutional authority dynamics of face-toface communities (Hoover 2016; Evolvi 2017; Lundmark 2019). However, Kołodziejska (2015) affirms that coherence between identity and messages in the virtual space is to be expected, as it is in the offline space. For Dawson and Cowan (2004), religion on the internet frequently refers to the offline space, and rarely exists exclusively in the digital space. According to these authors, the internet is both a mirror and a shadow of the offline space. For them, few aspects of the offline world are not present in the digital space; the corollary is that few aspects of the digital space do not have roots or references in the face-to-face world. Guzek (2019) analyses the digital traces of shared religious memory that strengthen the users' identity online, specifically in Facebook. Lundmark (2019) delves into aspects of the authority of religious vloggers and how they manage it to perform their identities. Lövheim and Lundmark (2019) study specifically how women's self-performances in digital media are characterized by a communicative intention towards authentic self-expression. They argue that "these self-performances also enable a particular form of authority to emerge, that is dependent on an individual's personal qualities and ability to inhibit and/or perform certain values".

Helland (2005) makes a distinction between the communities that are considered "religion online" and those that can be described as "online religion" (Díez-Bosch et al. 2018). For the author, the former makes instrumental use of the network, while the latter sees it and uses it as a social space where interaction is possible (Parish 2020). Davidson and Farquhar (2014) highlight that religious freedom in online communities can be inhibited by fear of rejection since on the internet, "the sender controls the message, but not always the audience." In this sense, Tridente and Mastroianni (2016) warn of the risk of the polarization of ideas in these spaces.

During the coronavirus pandemic, for many communities, telematic communication became, from one day to the next, the only possibility of maintaining contact with believers (Campbell 2020; Parish 2020) due to the restrictions imposed by the authorities to slow the spread of the disease. Faced with this scenario, bishoprics, parishes, religious congregations, movements, and suchlike implemented alternative communication strategies and systems. Digitalization provides new ways of establishing relationships and building communion (Sorice 2012) and although, historically, the Church has been a pioneer in the use of new platforms (Díaz Merchán 2017), as regards communication, and the media as spaces for 
dialogue even before the pandemic, the use of digital space was mostly instrumental (Díez-Bosch et al. 2018; Fiorentini 2012; Spadaro 2012; Helland 2005) and the possibility of creating a digital community met with certain resistance. This fact was evident in the different levels of digitalization that different communities found themselves in.

Parish (2020) studied the consequences of the "absence of presence" in face-to-face religious communities and, at the same time, of the "presence of absence" in them during confinement due to the pandemic. The author reasons that the coronavirus has brought new ways of understanding religious community belonging and participation. They underline that, although the pivotal nature of the face-to-face community remains essential in many groups, in the digital space, the religious community is unfolding with a new structure of digital-social interaction. Because of this, it abandons the link with a face-toface space-church or other place of worship; on the internet, the perception of "church" as a community rather than as a physical space or building is further reinforced.

Campbell (2020) highlights how the belief of or affiliation to a religion, specifically Christianity, has been measured in many cases by the criterion of the number of people attending ceremonies and celebrations. The author emphasizes that, also in the context of the pandemic and in an innovative environment, such as Christianity's digital space incarnation, traditional parameters have continued to be central to the assessment of faith in a religion, being translated into fidelity and monitoring the activity of a community.

We should note that communication is in the DNA and in the mission of the Catholic Church (Oesterheld 2016; Arasa 2012). Unlike what happens in most organizations whose organization charts include communication as a department at the service of the entity, the communicative aspect-in the case of the institution in question-is part of its very identity (Catela Marcos 2017; La Porte 2012). Because of this, we can affirm without fear of contradiction that a church that does not communicate is, in fact, not a church (Serrano Oceja 2019; Vera 2017; Beramendi 2016).

This particularity determines this community's form and function, which, as an institution, must also broadcast its nature and activity in a hyper-mediated world (Beramendi 2016; Viganó 2017). The public dimension has been key to the Christian faith since its inception (Volf and McAnnally-Linz 2016). Accordingly, the different ecclesial entities now have communication departments in charge of translating identity into image (Carroggio 2012). This is the objective of institutional communication, according to Dolphin (2000)—that identity and image coincide. An organization "does not manufacture its public image but deserves it, to the extent that the image is a reflection of reality" (Mora García de Lomas 2006, p. 165).

Given the Church's own identity, when addressing the commitment to new technologies, it is convenient to introduce the relational factor highlighted by Gabelas et al. (2015), going beyond the classical model and speaking of ICT (instead of IT) - Information and Communication Technology. This approach is more aligned with Christian anthropology and the foundations of Christian humanism (Orlandis 1985; Catela 2018) since, far from taking an instrumentalist viewpoint, the Church only perceives the media as being at the service of people and humanity at large (Francis Pope 2018; Pascual 1976).

Baraybar-Fernández et al. (2020) evaluate the use of social networks, Twitter, Facebook and YouTube by the Spanish Episcopal Conference and its strategy of creating a consolidated digital community. According to the authors, these networks are one of the most prominent platforms from which Catholics demonstrate their commitment to the Church, as they form a common space to share and celebrate their vision of the world. Soberón (2015) deems that online Catholic communities must learn, from secular or nonreligious ones, sensitivity for the creation of knowledge and the ability to deliberate to resolve issues.

We focus intently on assessing how a key issue has been resolved: the continuity of religious community life during a pandemic. Specifically, the digital response of the dioceses and archdioceses in Spain has been studied, taking into account that this is a 
prominent part of a consolidated, global, in-person community-the universal Catholic Church (Viana 1997; Pew Research 2020).

\section{Methodology}

The research at hand, which aims to analyze how the Spanish dioceses communication mechanisms responded to the crisis generated by the COVID-19 pandemic, was carried out electronically based principally on two techniques: surveys complemented by in-depth interviews. On one hand, the survey methodology was selected because it allows obtaining empirical data about this digital response of the Catholic Church. At the same time, it is a viable technique for measuring changes in behavior given that it facilitates obtaining not only basic data, but also opinions and attitudes about the topic consulted (Hansen et al. 1998) since the questionnaires can include both closed and open questions.

The 70 dioceses that make up the ecclesial map of the country (Spanish Episcopal Conference 2020) were selected as a sample-a representation of the activity of the Spanish Catholic community during the months of confinement-integrating all Catholic parishes and communities who are part of the Spanish Catholic community. Responses were obtained from 69 of these 70 dioceses (see Figure 1), amounting to $98.6 \%$ of the total sample-a percentage that amply confirms it as being representative.

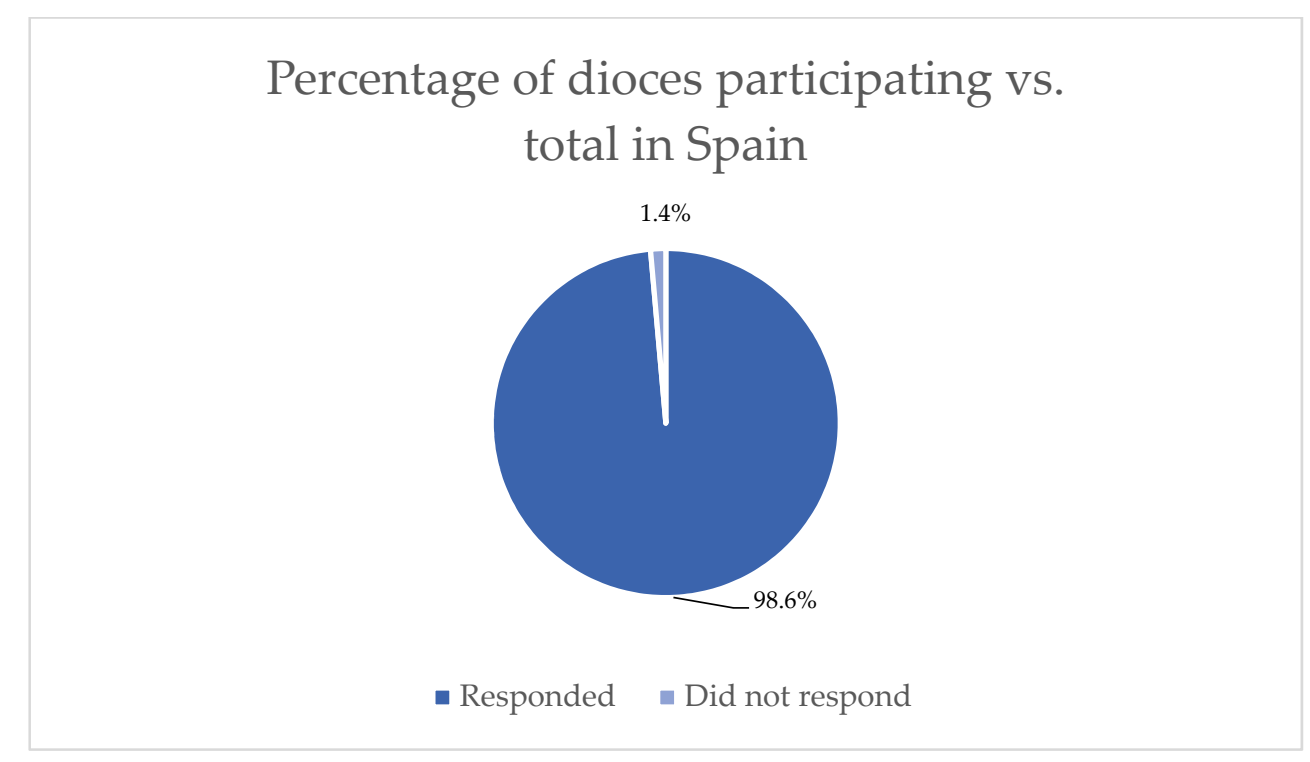

Figure 1. Percentage of participating dioceses vs. the total in Spain. Source: Authors.

The survey was carried out electronically using this quantitative/qualitative questionnaire (see Appendix A), comprising 16 questions divided into three sections. The first identifies the diocese and refers to the internal communication structure, the adaptation to the pandemic confinement situation, as well as the period involved. The second part addresses the type of digital solutions and platforms used by dioceses. In addition, it incorporates audience aspects and variations during the pandemic. Finally, the third section asks the respondents about the platforms used in the months of confinement and the future of the Spanish Church's digital communication based on the solutions implemented.

The fieldwork was carried out during the second stage of the state of alarm declared by the Spanish government and coincided with its end (between 2 May and 30 June 2020), at a time when the dioceses already were in possession of monitoring data related to COVID19 response activities and communication actions. It is worth noting that some similar previous research also used surveys as a methodology and, therefore, also corroborates the technique chosen; this would be the case of the research on religion experienced in Latin America by Morello et al. (2017), the study on youth, religion and new technologies by 
Díez-Bosch et al. (2018), and that of MacDonald et al. (2020) on the challenges of religious leaders during the COVID-19 pandemic.

The quantitative and qualitative results obtained from the described technique were complemented with an interview (Johnson 2002; Minichiello et al. 2008; Voutsina 2018). In this case, the inclusion of José Gabriel Vera's criteria was considered necessary, given that he is Director of the Secretariat of the Episcopal Commission for Social Communications and of the Information Office of the Spanish Episcopal Conference. This latter entity comprises all the bishops in each of the 70 Spanish dioceses, for the joint exercise of a number of functions (Spanish Episcopal Conference 2020). His testimony was considered pertinent given the context and actors involved, his position and his holistic vision of the situation.

\section{Results and Discussion}

Although a precise Spanish dioceses digital communication map is difficult to compile due to their heterogeneity, the research at hand does indeed highlight an appropriate and speedy reaction to the pandemic: $92.8 \%$ of the responding dioceses readapted their communication activity as a consequence of the COVID-19 pandemic and $67.2 \%$ of these did so in less than a week. Moreover, in $98.6 \%$ of the cases, those that did so achieved a significant growth in participation statistics in the use of the customary digital communication channels used in each diocese. The figures, as well as the José Gabriel Vera interview, corroborate the approach of authors such as Campbell (2020) and Parish (2020), in combination with the unprecedented speed of adaptation of the religious communities' digital spaces to the circumstance (Pou-Amérigo 2008; Díez-Bosch 2015).

Regarding the type of response, $77.8 \%$ adapted digital tools and initiatives that they already had in use, as well as launched digital-space-related new ones. All this activity was undertaken with five core objectives, according to the following analysis:

1. Respond to believers' needs: Above all, to attend to those who were attending to church before the state of alarm was declared, daily masses were streamed online, generic letters from the bishops were published in multimedia format, training material was disseminated, Parish Leaflets were shared on internet-in PDF format—or converted into electronic bulletins (newsletters). Parishioners' questions and doubts were channeled and, as in the case of the La Rioja region, a virtual parish was created, baptized as "The Virgin of Hope".

2. Be there for everyone, regardless of their religious beliefs: The effort of the Spanish dioceses to provide comfort and support to anyone and everyone in need is worth highlighting. In fact, although the actions aimed at believers were instigated to reach "the more people the better", the media delegations coordinated specific actions to welcome those who habitually did not participate in Church life. "You are not alone", "Close to you", "The Church is listening to you" and "Motivating messages" are some examples.

3. Attend to the needs of the media: The demand for information, according to the delegates themselves, "grew exponentially", with requests from local, regional and national media. This explains the trend in the results, which show an increase in the media relations with continuous and personalized treatment. Among the recurring themes, there are stories about the Church's work in fighting the pandemic, doubts about funerals and the testimonies of priests in hospitals and mortuaries.

4. Promote internal communication: To achieve the organizational objectives of effectiveness, efficiency and quality, there was a need for a "flow of information-communication and human relations" within the institutions themselves (Oyarvide-Ramírez et al. 2017). It is not surprising that, in a crisis like the one analyzed, the dioceses strengthened contact with priests in real time and maintained a smooth relationship with internal audiences to "maintain hope and ecclesiastical ties".

5. Support for transversal diocesan projects: The communication teams provided decisive support when disseminating and carrying out proposals throughout their diocese. It is worth highlighting the spiritual care services via telephone (aimed at the sick, and the families and professionals fighting the coronavirus), psychological and family care 
programs, prayer chains for the deceased, awareness campaigns and financing (emergency funds), and so on.

To meet these objectives, the combined use of various platforms, channels and networks was recurrent, comprising institutional websites (in $98.6 \%$ of the dioceses) with a specific category to group all the information regarding COVID-19: YouTube (89.9\%), to broadcast masses, prayers and meditations; Facebook (84.1\%); Twitter (79.7\%); Skype and other videoconferencing platforms (56.5\%); and Instagram (53.6\%), in addition to those categorized as "Others". Examples is this latter category are Mailchimp (to send newsletters by email); WhatsApp, with distribution lists segmented by audience (priests, the faithful in general, press); Ivoox (audios/podcast); Issuu (to facilitate the interactive reading of PDF publications); Vimeo; Flickr; Renderforest; and Telegram.

Figure 2 indicates that during the pandemic, the use of those platforms allowed virtually carrying out the usual acts of the community (masses, ceremonies, rituals) in a format that adhered quite realistically to being present. Thus, those spaces that allowed live video, image and instant content gained prominence: The Institutional Web; YouTube; Facebook, which enables its users establish links to share information, mainly through messages, links, videos and photographs; and Twitter, ideal for communicating news, alerts, agenda events, videos published by the institution, broadcasting events and for dialogue and collaboration (Barrionuevo-Almuzara et al. 2014).

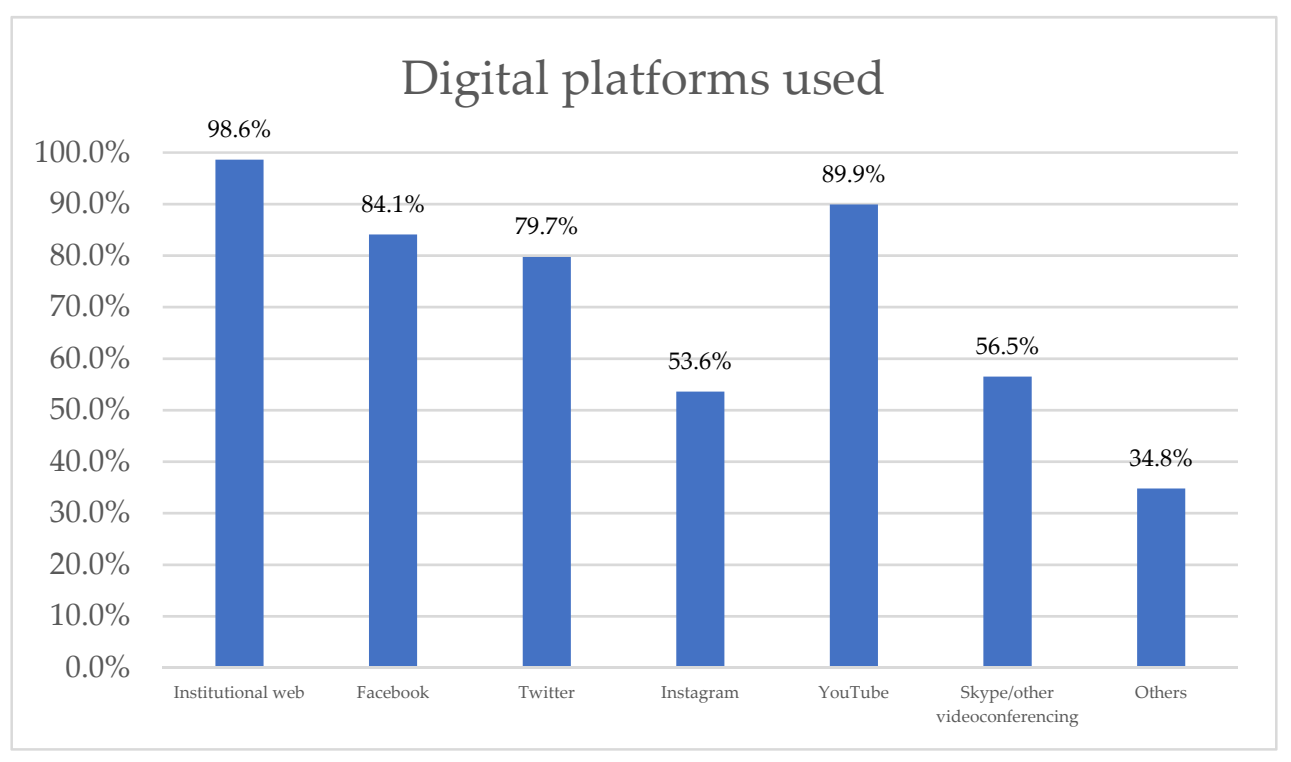

Figure 2. Digital platforms used by the diocese. Source: Authors.

This research compared the use made of these platforms by dioceses before and after the onset of the coronavirus pandemic (see Figure 3). The data show how the institutional website was a space that was used not only before the pandemic but also afterwards, although for different purposes. Before, it was used to publish information; then subsequently, this website was also used additionally to directly broadcast the events hosted on YouTube or even on local television. We should take note of the slight decrease in the use of Facebook and Twitter during the pandemic, and an increase in two other platforms: YouTube (an increase from $79.7 \%$ of dioceses to $89.9 \%$ ) and Skype and other video calling platforms (an increase from $20.3 \%$ of the dioceses to $56.5 \%$ ).

As regards the increase in the percentage in the "Other" category, the results also show the dioceses' desire for digital innovation given that, in record time, they searched for new spaces and digital tools specifically adapted to each regular face-to-face activity of the religious community in question. This continuation of regular activity included the celebration of masses, publication of parish sheets, diffusion of daily prayers, and suchlike through various platforms, such as Issuu, Vimeo, Rendforest and Flickr. 


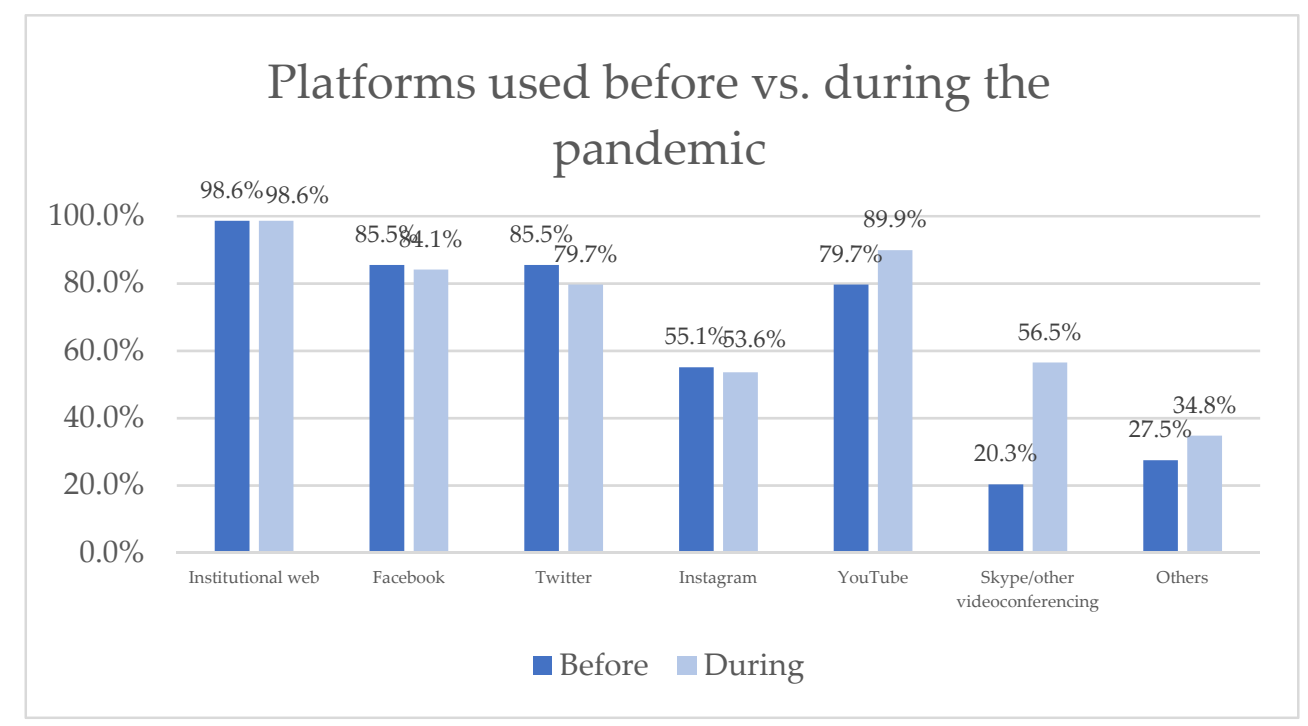

Figure 3. Digital platforms used by the diocese before vs. after the onset of the pandemic. Source: Authors.

Despite this, according to Campbell (2012); Helland (2005); and Lajoie (1996), although digital communities extend the reach of physical ones, they cannot replace being there in person. The coronavirus crisis has questioned this approach and has shown that the challenge of a face-to-face community, such as the Catholic Church, is to integrate the online and offline worlds. Faced with confinement, the Church was forced to offer virtual care and services without any type of face-to-face support, triggering a profound reinvention of day-to-day practices (Vera 2020), although it does not seem that all have come to stay.

The Director of Communication of the Spanish Episcopal Conference (CEE), José Gabriel Vera, considers that the reaction was both necessary and satisfactory, but concurs with the aforementioned authors that digital activity has not been able to completely replace the face-to-face one. "Our mission is to announce, celebrate and share, and we have not been able to celebrate in community; YouTube mass has improved the Christian life of the believers, but I do not consider that they have celebrated". Nevertheless, Parish (2020) underlines how the concept of "Church" is closely linked to a space and a time, and that digitalization further reinforces its meaning of "community" based on a belief or faith, be it an action which is face-to-face or digital.

At the same time, Vera (2020) admits that overcoming the time-space barrier has brought to the community old members who lived far afield, or new members who might not feel comfortable attending a celebration in person, rather preferring to do so under the cloak of digital anonymity. This highlights the need to create a "welcoming ministry", with people trained to welcome to the parishes those who have encountered the Church on the internet. Digital actions would then give way to physical celebration, "where it is possible to experience all the dimensions of faith." The internet would facilitate not only this initial contact, but it would also strengthen the face-to-face communities through a permanent bond and connection. Likewise, the internet would help community leaders-priests and pastoral agents-to promote aspects, such as the celebration of masses or social action (an example of which would be accompanying groups of the sick or elderly from different places via telematic meetings) threatened by phenomena such as rural depopulation.

The results of the study confirm the capacity of the digital space to keep physically constituted communities alive in the parishes, since "the faithful have found a way to be united with each other and with the Church, despite distances." At the same time, they endorsed their suitability for new relationships to be established. Not surprisingly, thanks to social networks and spaces, such as electronic mailboxes on their web pages, the dioceses have interacted "with people who had spiritual concerns and were searching for God and the meaning of life." Initiatives such as the Tierra Santa Challenge, from the diocese of La 
Rioja, broaden the profile of the participants in terms of age, and address a new generation that will be the one that will be able to hybridize online and offline spaces (Helland 2005; Parish 2020), in each case maximizing the possibilities within the relevant context.

This increase in participation is also evidenced quantitatively. The study shows an increase in almost all the dioceses $(98.6 \%)$. A total of $86.8 \%$ retained the same users as always but also reached out to embrace new ones. Although $8.8 \%$ of the delegates reported some loss of regular members of the community, as they could not reach those informed only through the printed publications that stopped being printed, the balance was positive, because, as these delegates state, "even many older people who did not have access to the digital offering made an effort to get into the new technologies and have not been left out".

Specifically, the number of diocesan subscribers on YouTube has increased: profiles that, starting from scratch, in a few days exceeded the thousand subscribers that this platform requires to be able to broadcast live. Traffic also increased on institutional web pages (in some cases, the number of unique users skyrocketed by more than $200 \%$ ) and on social networks (Facebook, Twitter and Instagram, in that order, with more gradual rises in both followers and interaction). This confirms that, in practice, the digital environment is conducive to engagement in Catholic communities, as stated by Díez-Bosch et al. (2015) when they highlight that the digital arena has become "one of the most prominent ways in which Catholics have found a common ground to share and celebrate their world vision". Figure 4 shows the increase in participants by platform according to the response of the different dioceses. It is of note that $73.5 \%$ of them report audience growth in YouTube, $64.7 \%$ in the institutional website and $60.3 \%$ in Facebook.

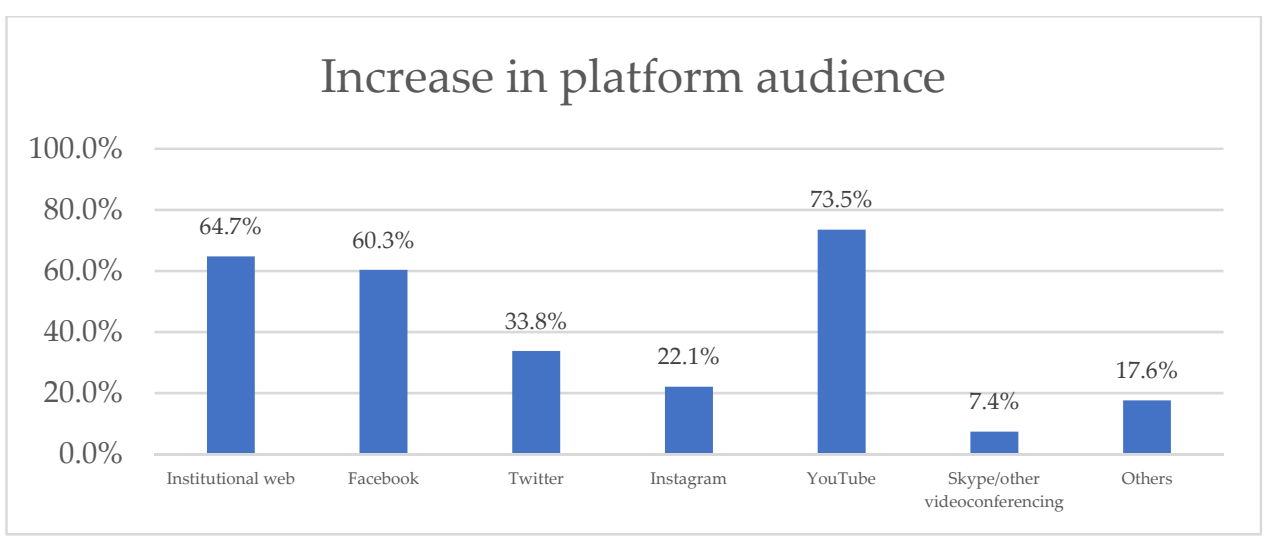

Figure 4. Increase in participants by platform. Source: Authors.

We should note that coincidentally, the pandemic confinement coincided with one of the periods of the year in which the activity of the Catholic community is highest and most solemn-Easter-at which time, participation in the face-to-face community already tends to increase, as commented in the Malaga diocese. This concurrence also appeared in other religions: Judaism, with the online celebration of Pesah; Islam, with a digital celebration of Ramadan; and Sikhism, commemorating their Vaisakhi or harvest festival.

The results also show that the rapid switch to digital platforms did not translate into 100\% digitalization. As Campbell (2020) asserts, belief in a religion, especially in Christianity, continues to be measured by quantitative participation in community action. In the online space, despite the fact that conventional space-time limits are interrupted (Parish 2020; Vera 2020), the criterion remains. In short, it was an accelerated digitalization, retaining a face-to-face essence, but showing a clear determination and ability to take the digital space increasingly into account.

In the community in question, Vera (2020) confirms that all dioceses took a step forward in terms of digitalization in the context of a pandemic, although he admits the limitations of some. He highlights that: "All have given what they could, according to their possibilities." The research at hand confirms the communicative strength of Madrid 
and Barcelona, among other territories, and reveals a series of difficulties when it comes to articulating the response in small dioceses:

The results in Figure 5 reveal that the main obstacles that the Spanish Catholic community encountered for the full digitalization of its activity in the context of a pandemic were the lack of equipment and human resources. Dioceses often overcame these obstacles with strategic alliances of various kinds. On one hand, agreements were signed with local and regional televisions to broadcast masses, both daily and on designated dates (Sundays and Easter). On the other hand, this type of collaboration with public and private entities made it possible to install fixed cameras in cathedrals and churches so that it is possible to pray from home, $24 \mathrm{~h}$ a day, without losing commitment. Another example is that Euskaltel and the Bishopric of Bilbao used artificial intelligence to reach parishioners, and the Aragonese Radio and Television Corporation collaborated with the Archdiocese of Zaragoza so that, from anywhere in the world, an immersive experience could be had in the Pilar Cathedral.

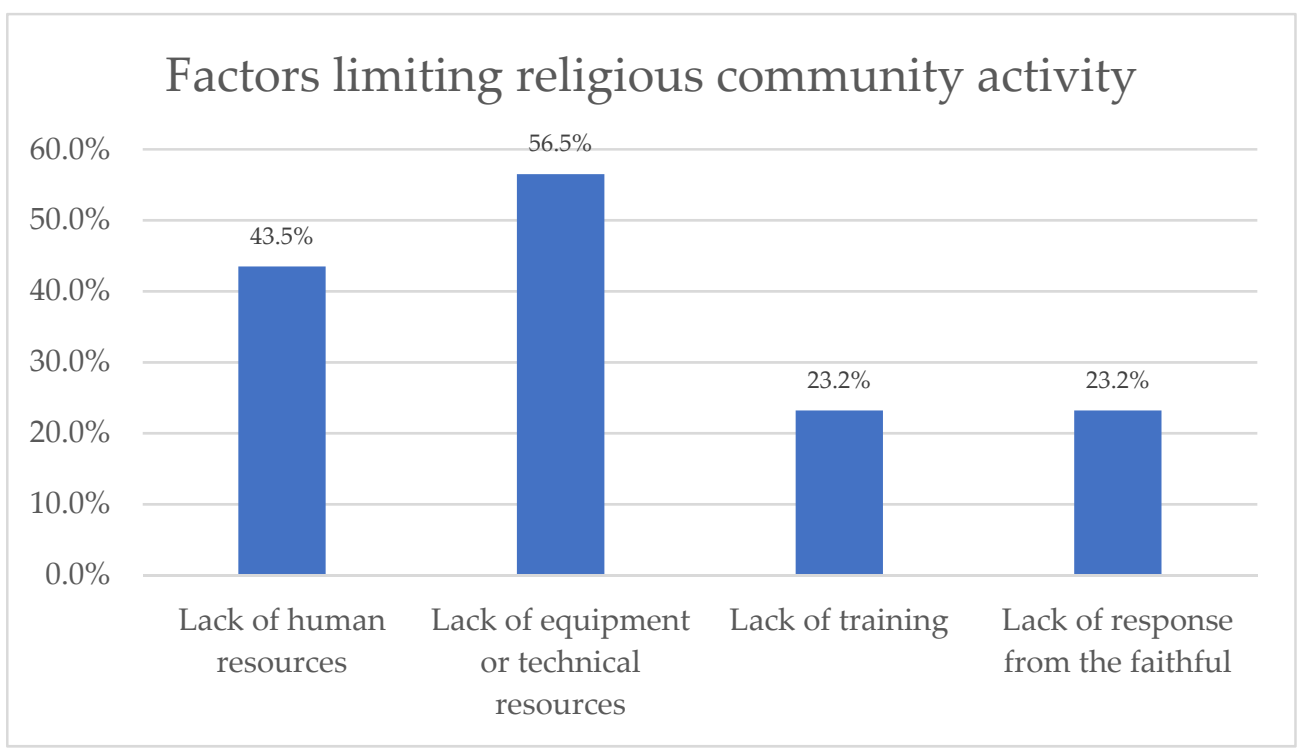

Figure 5. Limitations found by the community for digitalization. Source: Authors.

Despite the opportunity that digitalization has presented us with in this context, the lack of coordination when implementing it also threatens the communicative sphere of the Catholic community in Spain. Beramendi (2016) warns that the institution does not always act in a network, resulting in "cultural" and "structural" problems. Institutional communication in the 21st century requires maximum coordination and that those responsible are part of the bodies for which decisions are made (De la Cierva 2014), which is something that does not always happen. However, the research at hand reflects that the Spanish dioceses, as a community as a whole, are heading in the right direction. A total of $50.7 \%$ have a designated crisis committee in which the communication department is represented, which then ceases to be a purely technical secretariat and participates in the definition of strategies; $37.7 \%$ of them do not yet have this body, while the remaining $11.6 \%$ do, but do not have a designated communication director.

Some days before the state of alarm was decreed, the media delegates who participated in the crisis committee and the government council meetings highlighted how this facilitated their work and favored the diocese' reaction in the different phases of the pandemic, thanks to continuous monitoring. Conversely, those who did not have the opportunity to participate in these meetings considered this to be an added difficulty, which "slowed down the reaction" and favored the appearance of doubts "about communication skills, mainly between the secretariat-chancellery and the communication department".

Apart from this presence, the media delegations of the dioceses increased their work rate to adapt to the new scenario and provide service centered on the five aforementioned 
objective areas, in support of the community. An additional effort, one of "maximum" or "pushing limits" delivery according to some officials, has not gone unnoticed. Of those surveyed, $89.7 \%$ think that this crisis has made their diocese, especially the bishop or archbishop and the governance team, realize the importance of having a well-defined ("solvent and responsive") communication strategy.

One of the pending challenges is to promote the continuous training of those dedicated to Church communications (Vera 2020). Whilst it is true that the confluence of interests in online Catholic communities circumvented technical weaknesses that might have impeding their deployment (Helland 2005), improving the quality of institutional communication is decisive so that the public image of the Church correctly reflects its identity and daily work. On this path of professionalization, $100 \%$ of the delegates consider that this crisis will help complete the adaptation of a community, such as the Church, to the contemporary media context.

\section{Conclusions}

The Catholic community, entrenched in face-to-face action (Díez-Bosch et al. 2018), has taken an unprecedented step forward toward digitalization during the confinement declared (Government of Spain, RDL 463/2020, of 14 March 2020) due to the COVID-19 crisis in Spain. Of the 69 dioceses studied, $67.2 \%$ readjusted their communicative activity in less than a week.

This digital response was aimed at overcoming five different types of challenges:

1. Respond to believers' religious needs;

2. Be there for everyone, regardless of their religious beliefs;

3. Attend to the needs of the media;

4. Promote internal communication;

5. Support transversal diocesan projects.

Responses are grouped into the three major actions that, according to José Gabriel Vera, director of the Secretariat of the Episcopal Commission for Social Communications and of the Information Office of the Spanish Episcopal Conference, configure the mission of a community, such as the Catholic Church: to announce, to celebrate and to share. Above all, Vera (2020) acknowledges that the digital space has allowed advertising and sharing, although the celebration itself was more difficult to carry out. For this reason, this virtual space, despite being an extension of the face-to-face experience (Parish 2020), cannot replace it (Lajoie 1996; Helland 2005; Campbell 2012), not even under the extreme conditions that a pandemic entails.

The dioceses' use of different digital platforms reinforces this hypothesis. Moreover, the fact is that the activity has been displaced mainly to those virtual spaces that allow celebration of community activity that is quite faithful to the in-person format. The mostused channels were the dioceses' corporate websites and YouTube, followed by Facebook and Twitter, due to the immediacy that they provide. The community already was active on these platforms in a pre-pandemic context, but the increase in the use of YouTube, comparing pre- to post-pandemic contexts, was quite notable. This is shown in Figure 3. Similarly, the growth in the use of video conferencing tools has been remarkable. In fact, as Campbell (2020) assures us, belief in a faith is still measured by the criteria devised in a face-to-face world, such as attendance at its celebrations and community activity.

YouTube is the platform whose audience increased the most in the diocesan environment. The Catholic community connected to their respective parishes' channels from anywhere and at any time. This break with fixed times and spaces contributed to increasing the number of community members. In $86.8 \%$ of the dioceses, not only the same existing members participated, but also new ones were reached. Some digital partakers had not been able to participate in conventional face-to-face activity because they resided in another town or country; others joined the community thanks to the anonymity provided by the digital space, finding answers to spiritual concerns in this way. 
The creativity of some communities and the characteristics of the digital world also led to variations in the average age of community members. The presence of more young people was detected in some dioceses, as well as an older-generation surge. However, we should not forget that in a limited number of cases, a certain digital gap left behind members of the community who, due to lack of knowledge or accessibility, were not able to participate in the digital activity: some $9 \%$ of dioceses admit to having lost some members, despite gaining other new ones.

If previously the Catholic community was considered to be at the "religion online" stage, this crisis has brought it closer to "online religion" (Helland 2005) since the community regarded the digital world as simply a space rather than an instrument to experience religious activity (Campbell 2020; Parish 2020). Nevertheless, the coronavirus pandemic has not been synonymous with $100 \%$ digitalization in terms of maximum exploitation of the digital world's possibilities. As the relevant responses show, the activity is broadcast, the news is announced, but there is not always interaction or dialogue.

In the Spanish dioceses, the lack of equipment and human resources seem to be the most prominent factors limiting a fully digital response; this is also negatively affected by the lack of training and follow-through by some members of the community.

As institutional leaders of the Catholic community, dioceses must provide the maximum response and coordination necessary for 21st century institutional communication (De la Cierva 2014). In Spain, 50.7\% feature a crisis committee in which the communication department is represented. Effective coordination facilitated the dioceses' rapid reaction at the time of confinement and translated into future learning for the Catholic Church community: there is a clear need for the professionalization of those responsible for communication so that, in extreme situations such as that of the COVID pandemic, offline-online hybridization makes it possible for the community to continue its activity normally.

We should note that this study portrays the situation based on the actions of the leaders and the institutions that represent the Spanish Catholic community. Future research might measure this same response from the point of view of the participants.

Author Contributions: Conceptualization, A.S.G., J.M.A.A. and M.D.B.; Formal analysis, A.S.G., J.M.A.A. and M.D.B.; Investigation, A.S.G., J.M.A.A. and M.D.B.; Methodology, A.S.G., J.M.A.A. and M.D.B.; Project administration, A.S.G., J.M.A.A. and M.D.B.; Supervision, M.D.B.; Validation, M.D.B.; Writing-original draft, A.S.G., J.M.A.A. and M.D.B.; Writing-review \& editing, A.S.G., J.M.A.A. and M.D.B. All authors have read and agreed to the published version of the manuscript.

Funding: This research received no external funding.

Acknowledgments: Communication delegations from the 70 dioceses of Spain, Episcopal Commission for Social Communications of the Spanish Episcopal Conference, José Gabriel Vera, José Beltrán, Adriana Chiva.

Conflicts of Interest: The authors declare no conflict of interest.

\section{Appendix A. Questionnaire Implemented}

Diocese:

1. Does your diocese have a Crisis Committee or similar?

$\square$ Yes, but Communications is not part of it.

$\square$ Yes, and the Communication department is represented in it.

$\square$ No, there is no Crisis Committee.

2. Has your diocese readjusted its communication activity since the beginning of the state of alarm in Spain caused by the COVID-19 pandemic?

$\square$ Yes, it has.

$\square$ No, it has not. 
3. If yes, have you adapted initiatives and/or tools that were already in use or have new ones been implemented?

$\square$ We have readapted initiatives and/or tools that we already used.

$\square$ We have implemented new initiatives and/or tools.

$\square$ Both the previous two: we have readapted some and implemented new ones.

4. Although not all communication services will have been incorporated at the same time, in general terms, how long did it take to adapt the communication strategy to the digital space?

$\square$ Less than a week.

$\square$ More than a week.

$\square$ Less than a month.

$\square$ More than a month.

5. What difficulties did you encounter in articulating your communicative response? (You can check several options)

$\square$ Lack of human resources.

$\square$ Lack of equipment or technical resources.

$\square$ Lack of training.

$\square$ Lack of follow-up by parishioners.

$\square$ Other.

$\square$ None.

6. What platforms have you used? (You can check several options)

$\square$ Institutional website.

$\square$ Facebook.

$\square$ Twitter.

$\square$ Instagram.

$\square$ YouTube.

$\square$ Skype or other video calling systems.

$\square$ Other.

6.1 If you have answered "Others", could you indicate which ones?

7. On what platforms do you usually operate?

$\square$ Institutional website.

$\square$ Facebook.

$\square$ Twitter.

$\square$ Instagram.

$\square$ YouTube.

$\square$ Skype or other video calling systems.

$\square$ Other.

7.1 If you answered "Other", could you indicate which ones?

8. Could you summarize what the communicative response of your diocese has been to this crisis? You can highlight new projects or services, others that have been interrupted or suppressed, the intensification of activity on specific platforms ... Please give an open response to what you consider of interest.

9. Have you seen your audience increase?

$\square$ Yes, we have.

$\square$ No, we have not. 
10. If you have answered "yes" to the previous question, could you estimate how much it has increased compared to the three months prior to the onset of the crisis? (You can answer by offering an approximate percentage).

11. Where has there been the greatest increase? (You can check several options)

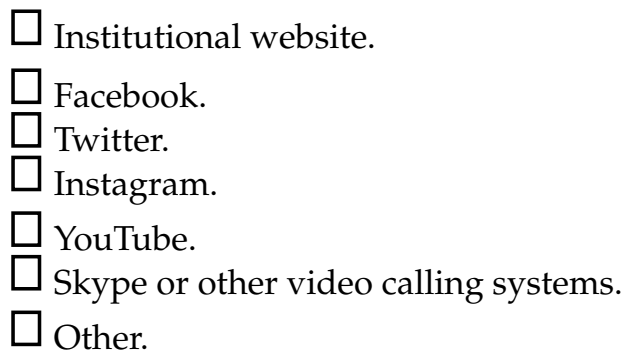

11.1 If you have answered "Others", could you indicate which ones?

12. About the audience profile during this crisis ...

$\square$ They have always been the same readers/users.

$\square$ They have remained the same readers/users and we have reached new ones.

$\square$ We have lost regular readers/users, but we have gained new ones.

13. If you have reached new users, could you briefly outline the profile/characteristics of those new readers/users?

14. Do you think that, after this crisis, any communicative practices of those implemented will remain in your diocese?

$\square$ Yes, this crisis will improve diocesan communication.

$\square$ No, it will not.

15. Do you think that this crisis has made your diocese, especially the governance team, recognise the importance of having a well-defined communication strategy (solvent and responsive)?

$\square$ Yes, I do.

$\square$ No, I do not.

16. Beyond your diocese, do you think this crisis could help complete the adaptation of the Catholic Church to the contemporary media context?

$\square$ Yes, I do.

$\square_{\text {No, I do not. }}$

\section{References}

Abdel-Fadil, Mona. 2017. Identity Politics in a Mediatized Religious Environment on Facebook: Yes to Wearing the Cross Whenever and Wherever I choose. Journal of Religion in Europe 10: 457-86. [CrossRef]

Aguirregomezcorta, Marta. 2020. La Iglesia pide a sus feligreses que no vayan a misa para evitar la propagación del coronavirus. Niusdiario.es. Available online: https:/ / www.niusdiario.es/sociedad/sanidad/diocesis-iglesia-coronavirus-cierran-templosno-asistir-misa-domingos_18_2914020046.html (accessed on 31 March 2021).

Arasa, Daniel. 2012. El magisterio de la Iglesia católica sobre la comunicación. In Introducción a la comunicación institucional de la Iglesia. Edited by José María La Porte. Madrid: Palabra.

Augé, Marc. 1994. Los 'no lugares'. Espacios del anonimato. Una antropología de la sobremodernidad. Barcelona: Gedisa.

Baraybar-Fernández, Antonio, Sandro Arrufat-Martiin, and Rainer Rubira-Garcia. 2020. Religion and Social Media: Communication Strategies by the Spanish Episcopal Conference. Religions 11: 239. [CrossRef]

Barber, Elizabeth. 2020. Will the Coronavirus be the End of the Communion Cup? The New Yorker. Available online: https: //www.newyorker.com/news/on-religion/will-the-coronavirus-be-the-end-of-the-communion-cup (accessed on 24 May 2020).

Barrionuevo-Almuzara, Leticia, Eva Estupinyà-Pinyol, $\mathrm{M}^{\mathrm{a}}$ Carmen Martín Marichal, Helena Martín-Rodero, Javier Mezquita-Acosta, Brigit Nonó-Rius, and Cristina Vaquer Suñer. 2014. Manual de buenas prácticas en redes sociales. Madrid: CRUE Rebiun.

Beramendi, Ariel. 2016. Apuntes para una pastoral de la comunicación hoy. Los desafíos del nuevo ambiente digital. Bogotá: PPC. 
Binder, Melanie. 2020. Online Community Value is Apparent Amid the COVID-19 Outbreak. Healthcare Financial Management Association. Available online: https://www.hfma.org/topics/hfm/2020/may/online-community-value-is-apparent-amidthe-COVID-19-outbreak.html (accessed on 29 March 2021).

Caldwell, Hellen, and Michelle Bugby. 2018. The use of technology to build digital communities. In Young Children and Their Communities: Understanding Collective Social Responsibility. Edited by Gillian Sykes and Eleonora Teszenyi. London: Routledge.

Campbell, Heidi. 2005. Exploring Religious Community Online. We are One in the Network. New York: Peter Lang Publishing.

Campbell, Heidi. 2012. Understanding the relationship between religion online and offline in a networked society. Journal of the American Academy of Religion 80: 64-93. [CrossRef]

Campbell, Heidi. 2020. Religion in Quarantine: The Future of Religion in a Post-Pandemic World. Austin: Digital Religion Publications.

Campbell, Heidi. 2021. Digital Creatives and the Rethinking of Religious Authority. London: Routledge.

Campbell, Heidi, and Stephen Garner. 2016. Networked Theology. Negotiating Faith in a Digital Culture. Grand Rapids: Baker Academic.

Carroggio, Marco. 2012. La oficina de prensa y la relación con los medios. In Introducción a la comunicación institucional de la Iglesia. Edited by José Maróa La Porte. Madrid: Palabra.

Casero-Ripollés, Andreu. 2020. Impact of COVID-19 on the media system. Communicative and democratic consequences of news consumption during the outbreak. El profesional de la información 29. [CrossRef]

Castells, Manuel. 2001. La Galaxia Internet: Reflexiones sobre internet, empresa y sociedad. Barcelona: Plaza y Janés.

Catela, Isidro. 2018. Me Desconecto, Luego Existo. Madrid: Encuentro.

Catela Marcos, Isidro. 2017. La comunicación institucional de la Iglesia. In The Challenges of the Catholic Communicator. Edited by Rafael Ortega and Álvaro de la Torre. Madrid: CEU.

Celia Perera, Ana, and O. Pérez Cruz. 2009. Crisis social y reavivamiento religioso. Una mirada desde lo sociocultural. Cuicuilco 16: 135-57.

Celli, Claudio Maria. 2013. La comunicación de la fe en el horizonte de la nueva evangelización. Catholic.net. Available online: https:/ /goo.gl/d5ov89 (accessed on 15 March 2021).

Davidson, Theresa, and Lee K. Farquhar. 2014. Correlations of social anxiety, religion, and Facebook. Journal of Media and Religion 13: 208-25. [CrossRef]

Dawson, Lorne, and Douglas Cowan. 2004. Religion Online. Finding Faith on the Internet. New York and London: Routledge.

De la Cierva, Yago. 2014. La Iglesia, casa de cristal. Madrid: BAC.

Díaz Merchán, Gabino. 2017. Evangelizar en un mundo nuevo. Reflexión pastoral sobre la nueva evangelización en España. Madrid: PPC.

Díez-Bosch, Míriam. 2015. Perfil del informador religioso especializado en el Vaticano. Palabra Clave 18: 258-75. [CrossRef]

Díez-Bosch, Míriam, Josep-Lluís Micó-Sanz, and Josep-Maria Carbonell-Abelló. 2015. Catholic Communities Online. Barcelona: Blanquerna Observatory on Media, Religion and Culture.

Díez-Bosch, Míriam, Josep-Lluís Micó-Sanz, and Alba Sabaté-Gauxachs. 2018. Construcción de comunidades online a partir de comunidades presenciales consolidadas. El caso de la Iglesia católica en internet. El Profesional de la Información 27: 1699-2407. [CrossRef]

Dolphin, Richard R. 2000. The Fundamentals of Corporate Communication. Oxford: Butterworth Heinemann.

Eilers, Franz-Josef. 1994. Communication in Community. Manila: Logos Publications.

Evolvi, Giulia. 2017. Hybrid Muslim identities in digital space: The Italian blog Yalla. Social Compass 64: 220-32. [CrossRef]

Fiorentini, B. 2012. Accesso alla rete in corso. Dalla tradizione orale a internet, 2000 anni di storia della comunicazione della Chiesa. Bologna: EDB.

Fischer, Sara. 2020. Social media use spikes during pandemic. Axios. Available online: https://www.axios.com/social-media-overusespikes-in-coronavirus-pandemic-764b384d-a0ee-4787-bd19-7e7297f6d6ec.html (accessed on 15 March 2021).

Francis Pope. 2018. La verdad os hará libres (Jn 8, 32). Fake news y periodismo de paz. Vatican.va. Available online: http: / / www.vatican.va/content/francesco/es/messages/communications / documents / papa-francesco_20180124_messaggiocomunicazioni-sociali.html (accessed on 15 March 2021).

Gabelas, José Antonio, Carmen Marta-Lazo, and Patricia González-Aldea. 2015. El factor relacional en la convergencia mediática: Una propuesta emergente. Anàlisi. Quaderns de Comunicació i Cultura 53: 20-34.

González, Beatriz. 2020. La crisis del coronavirus reactiva el sentimiento religioso. Uoc.edu. Available online: https:/ /www.uoc.edu/ portal/es/news/actualitat/2020/189-crisis-coronavirus-reactiva-religion.html (accessed on $15 \mathrm{March}$ 2021).

Government of Spain. 2020. Real Decreto 463/2020, de 14 de marzo, por el que se declara el estado de alarma para la gestión de la situación de crisis sanitaria ocasionada por el COVID-19. Boletín Oficial del Estado, n. 67. Available online: https: / / www.boe.es/buscar/act.php?id=BOE-A-2020-3692 (accessed on 5 March 2021).

Graham, Gordon. 1999. The Internet: A Philosophical Inquiry. London: Routledge.

Gupta, Sumeet, and Hee-Woong Kim. 2004. Virtual community: Concepts, implications, and future research directions. Paper presented at 10th America's Conference on Information Systems, Singapore, April 10.

Guzek, Damian. 2019. Religious memory on Facebook in times of refugee crisis. Social Compass 66: 75-93. [CrossRef]

Hansen, Anders, Simon Cottle, Ralph Negrine, and Chris Newbold. 1998. Mass Communication Research Methods. New York: NYU Press.

Helland, Christopher. 2005. Online religion as lived religion. Methodological issues in the study of religious participation on the internet. Online-Heidelberg Journal for Religions on the Internet 1: 1-16. 
Hjarvard, Stig. 2011. The mediatisation of religion: Theorising religion, media and social change. Culture and Religion 12: 119-35. [CrossRef]

Holtzman, Steven R. 1994. Digital Mantras. The Languages of Abstract and Virtual Worlds. Cambridge: MIT Press.

Hoover, Stewart M. 2006. Religion in the Media Age. New York: Routledge.

Hoover, Stewart M. 2016. The Media and Religious Authority. University Park: Penn State University Press.

Hoover, Stewart M., and Nadia Kaneva. 2009. Fundamentalisms and the Media. New York: Continuum.

Igartua, Juan José, Félix Ortega-Mohedano, and Carlos Arcila-Calderón. 2020. Communication use in the times of the coronavirus. A cross-cultural study. El profesional de la información 29. [CrossRef]

Johnson, John. 2002. In-depth interviewing. In Handbook of Interview Research: Context and Method. Edited by Jaber F. Gubrium and James A. Holstein. London: Sage, pp. 103-19. [CrossRef]

Kim, Amy-Jo. 2000. Community Building on the Web: Secret Strategies for Successful Online Communities. Boston: Addison-Wesley Longman Publishing.

Koeze, Ella, and Nathaniel Popper. 2020. The Virus Changed the Way We Internet. The New York Times. Available online: https: // www.nytimes.com/interactive/2020/04/07/technology/coronavirus-internet-use.html (accessed on 4 March 2021).

Kołodziejska, Marta. 2015. How Catholic internet forums are changing Catholicism. The Polish experience. In Catholic Communities Online. Edited by Miriam Díez-Bosch, Josep Lluís Micó-Sanz and Josep Maria Carbonell Abelló. Barcelona: Blanquerna Observatory on Media, Religion and Culture, pp. 35-48.

Kołodziejska, Marta. 2020. Mediated Identity of Catholic Internet Forum Users in Poland. Journal of Religion, Media and Digital Culture 9: 59-81. [CrossRef]

La Porte, José María. 2012. Introducción a la comunicación institucional de la Iglesia. Madrid: Palabra.

Lajoie, Mark. 1996. Psychoanalysis and cyberspace. In Cultures of Internet. Virtual Spaces, Real Histories, Living Bodies. Edited by Rob Shields. London: Sage Publications, pp. 160-61. [CrossRef]

Lövheim, Mia. 2004. Intersecting Identities: Young People, Religion, and Interaction on the Internet. Uppsala: Uppsala University Publications.

Lövheim, Mia, and Evelina Lundmark. 2019. Gender, Religion and Authority in Digital Media. Essachess: Journal for Communication Studies 12: 23-38.

Lowenthal, Patrick, Jared Borup, Richard West, and Leanna Archambault. 2020. Thinking Beyond Zoom: Using Asynchronous Video to Maintain Connection and Engagement During the COVID-19 Pandemic. Journal of Technology and Teacher Education 28: 383-91.

Lundmark, Evelina. 2019. "This is the Face of an Atheist": Performing Private Truths in Precarious Publics. Uppsala: Uppsala Universitet.

MacDonald, Andrew, Ed Stetzer, Tod Wilson, and Daniel Yang. 2020. How Church Leaders are Responding to COVID-19 Challenges: 2nd Round Survey. Christianity Today. Available online: https://www.christianitytoday.com/edstetzer/2020/april/how-churchleaders-are-responding-to-challenges-of-covid-19.html (accessed on 4 March 2021).

Minichiello, Victor, Rosalie Aroni, and Terrence Hays. 2008. In-Depth Interviewing: Principles, Techniques, Analysis. French Forests: Pearson Education Australia.

Mora García de Lomas, Juan Manuel. 2006. Dirección estratégica de la comunicación en la Iglesia. Revista Comunicación y Sociedad 9: 165-84.

Morello, Gustavo, Catalina Romero, Hugo Rabbia, and Néstor Da Costa. 2017. An enchanted modernity: Making sense of Latin America's religious landscape. Critical Research on Religion 5: 308-26. [CrossRef]

Oesterheld, Jorge. 2016. No basta con un clic. Iglesia y comunicación. Madrid: PPC.

Orlandis, José. 1985. Antropología y humanismo cristiano. Dios y el hombre. Pamplona: Servicio de Publicaciones de la Universidad de Navarra.

Oyarvide-Ramírez, Harold P., Edwin F. Reyes-Sarria, and Milton R. Montaño-Colorado. 2017. La comunicación interna como herramienta indispensable de la administración de empresas. Dominio de las Ciencias 3: 296-309. [CrossRef]

Parish, Helen. 2020. The Absence of Presence and the Presence of Absence: Social Distancing, Sacraments, and the Virtual Religious Community during the COVID-19 Pandemic. Religions 11: 276. [CrossRef]

Pascual, Javier María. 1976. Los medios de comunicación en la doctrina social de la Iglesia. Madrid: Servicio de Publicaciones del Ministerio de Educación y Ciencia.

Pew Research. 2020. 53\% of Americans Say the Internet has been essential during the COVID-19 Outbreak. Pew Research. Available online: https:/ / www.pewresearch.org/internet/2020/04/30/53-of-americans-say-the-internet-has-been-essential-during-thecovid-19-outbreak/ (accessed on 18 March 2021).

Piff, David, and Margit Warburg. 2005. Seeking for truth. Plausibility alignment on a Baha'i email list. In Religion and Cyberspace. Edited by Morten Hojsgaard and Margit Warburg. London: Routledge, pp. 86-101.

Pou-Amérigo, María José. 2008. El hecho religioso y su tratamiento periodístico: Limitaciones y dificultades. Estudios sobre el Mensaje Periodístico 14: 561-73.

Preece, Jenny. 2000. Online Communities: Designing Usability, Supporting Sociability. Industrial Management E Data Systems 100: 459-60. [CrossRef]

Reising, Richard. 2006. Church Marketing 101: Preparing Your Church for Greater Growth. Grand Rapids: Baker.

Rheingold, Howard. 1993. Virtual community: Homesteading on the electronic frontier. Reading: Addison-Wesley. 
Sánchez-Camacho, Jesús. 2020. El Covid-19 y la Iglesia: Una respuesta ciberreligiosa sin precedentes. Fpablovi.org. Available online: https:/ / www.fpablovi.org/index.php/covid-19-en-la-era-digital/963-el-covid-19-y-la-iglesia-una-respuesta-ciberreligiosasin-precedentes (accessed on 18 March 2021).

Serrano Oceja, José Francisco. 2019. La sociedad del desconocimiento. Comunicación posmoderna y transformación cultural. Madrid: Encuentro.

Soberón, Leticia. 2015. What we can learn from Secular Social Media Networks. Deliberating together: A new paradigm of dialogue in the net. In Catholic Communities Online. Edited by Míriam Díez-Bosch, Josep Lluís Micó-Sanz and Josep Maria Carbonell Abelló. Barcelona: Blanquerna Observatory on Media, Religion and Culture, pp. 35-48.

Sorice, Michele. 2012. Social media e Chiesa. Il tempo del dialogo. In L'etica della comunicazione nell'era digitale. Edited by Ignazio Sanna. Roma: Studium, pp. 123-41.

Spadaro, Antonio. 2012. Cyberteologia. Pensare il cristianesimo al tempo della rete. Milán: Vita e Pensiero.

Spanish Episcopal Conference. 2020. Iglesia en España. Available online: https://conferenciaepiscopal.es/iglesia-en-espana/mapaeclesiastico/ (accessed on 15 March 2021).

Statista. 2020a. COVID-19/Coronavirus. Facts and Figures. Statista. Available online: https://www.statista.com/page/covid-19 -coronavirus (accessed on 15 March 2021).

Statista. 2020b. Increases in Online Media Usage during the Coronavirus Pandemic in Germany, Spain, Netherlands, Italy, and Poland, as of March 2020. Statista. Available online: https:/ /www.statista.com/statistics/1110864/online-media-use-during-thecoronavirus-pandemic-europe/ (accessed on 15 March 2021).

Tridente, Giovanni, and Bruno Mastroianni. 2016. La Missione Digitale. Comunicazione della Chiesa e Social Media. Roma: Edizioni Santa Croce.

Turkle, Sherry. 1995. Life on Screen. Identity in the Age of the Internet. New York: Simon \& Schuster.

Vera, José G. 2017. Introducción. La Iglesia y la comunicación. In Los retos del comunicador católico. Edited by Rafael Ortega and Álvaro de la Torre. Madrid: CEU, pp. 15-20.

Vera, José G. 2020. Personal interview. June 8.

Viana, Antonio. 1997. Organización del gobierno de la Iglesia. Pamplona: Eunsa.

Viganó, Darío E. 2017. En salida. Francisco y la Comunicación. Barcelona: Herder.

Volf, Miroslav. 2015. Flourishing. Why We Need Religion in a Globalized World. New Haven and London: Yale University Press.

Volf, Miroslav, and Ryan McAnnally-Linz. 2016. Public Faith in Action. How to Think Carefully, Engage Wisely and Vote with Integrity. Grand Rapids: Brazos Press.

Voutsina, Chronoula. 2018. A practical introduction to in-depth interviewing. International Journal of Research $\mathcal{E}$ Method in Education 41 : 123-24. [CrossRef]

Wellman, Barry, Janet Salaff, Dimitrina Dimitrova, Laura Garton, Milena Gulia, and Caroline Haythornthwaite. 1996. Computer Networks as Social Networks: Collaborative Work, Telework, and Virtual Community. Annual Review of Sociology 22: 213-38. [CrossRef] 